\title{
Zsákmány és ragadozó együttélése agrárkörnyezetben: a mezei hörcsög (Cricetus cricetus) és a molnárgörény (Mustela eversmanii) napi és szezonális aktivitásmintázata kotorékoknál
}

\author{
CSERKÉSZ TAMÁs $^{1^{*}}$, KISS CSABA ${ }^{2}$ és OTTLECZ BARNABÁs ${ }^{2}$ \\ ${ }^{1}$ Magyar Természettudományi Múzeum Állattára, 1088 Budapest, Baross utca 13. \\ ${ }^{2}$ Bükki Emlőstani Kutatócsoport Egyesület, 3300 Eger, Maklári út 77/A \\ *E-mail: cserkesz.tamas@nhmus.hu
}

\begin{abstract}
Összefoglalás. A mezei hörcsög és a vadászatára nagymértékben specializálódott molnárgörény életmódját, illetve tavaszi és nyári napi aktivitási mintázatát Békés megye déli részén, egy $2 \mathrm{~km}$ hoszszú mezsgyeszakaszon vizsgáltuk kameracsapdákkal. Ezen a területen legalább 4-5 molnárgörény talált menedéket a kutatási időszakban, ami kifejezetten magas egyedsürüségnek számít ahhoz képest, hogy a molnárgörény az ország jelentős részéről eltűnt, vagy egyedsürüsége a kimutathatósági küszöb alatt lehet. A hörcsög szintén gyakori faj ezen a területen, helyenként mérgezéssel védekeznek ellene. Mindkét faj esetében a legmagasabb szezonális aktivitást tavasszal mértük; a magas aktivitás legvalószínübb okának a párzási időszakot jelöltük meg. Ekkor a hörcsög és a görény napi aktivitása nagyobb átfedést mutatott, mint nyáron $(\Delta 1=0,66$ tavasszal, illetve $\Delta 1=0,3$ nyáron). A görény aktív időszakának kezdete mindkét szezonban megelőzte a hörcsögét, és később is zárult annál, tehát lefedte a hörcsög aktivitási periódusát. Nyáron a mezsgyében lévő kotorékoknál kevesebb felvételt sikerült rögzíteni, ami valószínüleg annak köszönhető, hogy az állatok ebben az időszakban már többet tartózkodnak a szántóföldek magas vetéseiben, és nem szorulnak rá a mezsgye nyújtotta fedezékre. Nyáron a görény aktivitása megtartotta bimodális jellegét, a hörcsögé viszont ezzel ellentétes unimodális mintázatot mutatott, ami feltételezetten a ragadozók elkerülésére irányuló aktivitási válasz. A molnárgörény élőhelyén ritka látogatónak regisztráltuk a rókát, a görény egyik jelentős ragadozóját. A kevés róka Békés megyében elösegítheti az életképes molnárgörény populáció fennmaradását.
\end{abstract}

Kulcsszavak: vadkamera, kernel sürüség becslés, veszélyeztetett emlősfajok.

Elfogadva: 2020.04.13.

Elektronikusan megjelent: 2020.05 .08 .

\section{Bevezetés}

A molnárgörény (Mustela eversmanii LESSON, 1827) egy kevésbé ismert, veszélyeztetett palearktikus ragadozó emlősfaj. Rejtett életmódja és populációinak alacsony egyedsürüsége miatt vizsgálata nehézségekbe ütközik, így kevés információval rendelkezünk ahhoz, hogy reálisan meghatározzuk a populációkat veszélyeztető tényezőket, illetve a fajmegőrzéshez szükséges tevékenységek körét. Hasonlóan hiányosak az aktuális ismereteink egyik legfontosabb táplálékállatáról, a mezei hörcsögről (Cricetus cricetus LINNAEUS, 
1758), így a vizsgálatok hiánya mindkét faj esetében megnehezíti a hatékony védelmet. Napjainkban Magyarországon a hörcsög megítélése kettős: az ország egyes részein károkozásra is képes, ezért nagy területeken védekeznek ellene mérgezéssel, amely másodlagosan többek között a molnárgörény szervezetébe is bekerülhet, ami a pusztulását okozhatja. Példaként érdemes megemlíteni egy dániai kutatást, amiben a vizsgált közönséges görény (Mustela putorius) tetemek 93-95\%-ban mutatták ki rodenticidek maradványait (ELMEROS et al. 2018). Másrészről a hörcsög védelme is elötérbe került, hiszen Magyarországon sok helyen megritkult, vagy eltünt (CSERKÉSZ 2017), Nyugat-Európában veszélyeztetett, fokozottan védett fajnak számít (WEINHOLD 2008), továbbá számos ragadozó, pl. a parlagi sas fontos prédája (HoRVÁTH et al. 2018). A hörcsög és a molnárgörény is szerepel az Élőhelyvédelmi Irányelv védett fajok listáján, bár a hörcsög esetében Magyarország derogációt kért, amit meg is kapott. A molnárgörény jelenleg az IUCN Vörös Listáján a hörcsöghöz hasonlóan (KRYŠTUFEK et al. 2016) európai (TIKHONOV et al. 2007) és globális szinten is ,nem, vagy legkevésbé veszélyeztetett” (Least Concern) besorolású faj (MARAN et al. 2016). Mindkét fajról 2022-ig a GRASSLAND-HU LIFE IP projekt keretében megőrzési terv készül (http://www.grasslandlifeip.hu). Természetvédelmi szempontból további célunk, hogy a jelen tanulmányban bemutatott új eredmények és értékelésük tudományos szintü ismeretekkel alapozzák meg a tervezett fajmegörzési terveket. A molnárgörény védelme nem választható el legfontosabb táplálékállatának, a hörcsögnek a védelmétől. E két, eddig kevés figyelmet kapott faj természetvédelmi célú kutatásának magasabb prioritást kellene kapnia a jövőben.

Munkánkban vadkamerákkal vizsgáltuk a molnárgörény és a hörcsög aktivitását és viselkedését országunk egy olyan egyedülálló régiójában, ahol mindkét faj még gyakorinak tekinthető (CSATHÓ et al. 2016, OTTLECZ et al. 2019). Kérdéseink között szerepelt, hogy a zsákmány és az annak vadászatára magas szinten specializált ragadozó aktivitása között mekkora átfedés tapasztalható, illetve mennyire aktívak egymás kotorékának közelében. A vizsgálat további célja általános adatgyüjtés volt a mezei hörcsög és a molnárgörény ma még kevéssé ismert életmódjáról, szaporodásbiológiájáról, illetve természetes ragadozóikról és a populációikat veszélyeztető tényezőkről. Az agrár-élőhely életközösségében a molnárgörény a ragadozó és a zsákmány szerepét is egyaránt betölti, hiszen nem ő a csúcsragadozó a táplálékláncában, hanem a róka és a parlagi sas. Molnárgörényt zsákmányoló parlagi sasról FEFELOV (2004) és MEYBURG \& KIRWAN (2020) közölt adatokat, rókánál pedig OTTLECZ BARNABÁs figyelte meg ezt a viselkedést (OTTLECZ unpubl.).

A molnárgörényről hasonló vadkamerás vizsgálat még nem készült, bár a faj első észlelése Nepál területén kamerákkal végzett felmérésnek volt köszönhető (CHETRI et al. 2014). A mezei hörcsög esetében viszont készült már hasonló, aktivitást elemző vizsgálat: ALBERT et al. (2014) a hörcsög és ragadozóinak napi, illetve éves aktivitásáról szintén kamerák segítségével gyüjtöttek adatokat. Eredményeik szerint ősz felé haladva a hörcsög számára elérhető táplálék mennyiségének és a védelmet nyújtó vegetációs borítás csökkenésével a hörcsög és a ragadozóinak aktivitási csúcsa fokozatosan átfedésbe került. VILLEMEY et al. (2013) hörcsög-visszatelepítési akciókban használtak vadkamerákat és a visszatelepített egyedek szaporodási sikerét mérték az új területen született utódok száma alapján. 


\section{Anyag és módszer}

\section{Kutatási terület}

A felmérés helyszínéül a Békés megyei Mezőkovácsháza külterületét választottuk, amely tájföldrajzilag a Csanádi-hát kistájhoz tartozik a Körös-Maros közének legkeletibb részén. A kistáj 97 és 104 méter közötti tengerszint feletti magasságú lösziszappal fedett hordalékkúp-síkság; ortográfiai domborzattípusát tekintve pedig alacsony ármentes síkság. A felszínt - a nyugati rész elgátolt laposainak kivételével - mindenütt infúziós lösz, homokos lösz fedi (SÜMEGHY 1944, RÓNAI 1983). A legnagyobb arányban felszántott kistájaink egyike, a természetszerü növényzet erősen fragmentált. Az eredeti löszsztyepp-vegetáció maradványait jellemzően az utak, közigazgatási határok, erek mentén húzódó mezsgyék őrzik (KIRÁLY et al. 2008). Éppen kedvező földrajzi adottságainak (árvíz- és belvízmentesség, jól ásható lösz) is köszönhetően, a Csanádi-háton - Európában már egyedülállóan magas egyedszámú populációja található a hörcsögnek és a molnárgörénynek egyaránt. A mintavételi területen az élőhely változatos szántóföldi kultúrák között vezető, kisforgalmú földutat egyik oldalról szegélyező 5-20 méter széles fás bozótos mezsgye $2 \mathrm{~km}$ hosszú szakasza volt, ahol korábbi felméréseinkben magas egyedszámúnak mutatkozott mindkét faj állománya. A megtalált molnárgörény kotorékokról nyilvántartást vezettünk, sorszámmal jelöltük öket; a cikkben bemutatott megfigyelést a 7-es, 8-as és 99-es számú kotorékoknál végeztük el.

Az első felmérések 2018. decemberében kezdődtek, de ekkor még csak a kamerabeállításokat teszteltük; a tényleges monitoring 2019. márciustól kezdődött. A kamerák ellenőrzésére, az akkumulátorok cseréjére és a memóriakártyán tárolt felvételek lemásolására, legfeljebb havonta egy alkalommal került sor.

\section{Vadkamerák alkalmazása}

A kameracsapdázás az egyik leghatékonyabb és leginkább objektív módszere az állatközösségröl gyüjthető tér- és időbeli elöfordulási adatoknak (O'CONNELL et al. 2010, ROVERO \& ZIMMERMANN 2016). Különösen a rejtett életmódú fajok, így leginkább a ragadozók kimutatására és monitorozására alkalmas, akár nagyobb tér- és időbeli skálán is. Szükségtelen az állatokat csapdába ejteni és kézbe venni, ami állatvédelmi szempontból is előnyös, különösen, ha a hagyományos csapdázással hasonlítjuk össze, ami kíméletes protokoll követése mellett is kockázatot jelent a befogott állatok számára. További nagy elönye, hogy egyetlen beállítással egyidejüleg vizsgálható több szimpatrikus faj aktivitási mintázata, niche-átfedése, vagy szaporodása (BRIDGES \& NosS 2011). Statisztikailag viszont leginkább abban az esetben elemezhetők a módszerrel gyüjtött adatok, ha a kamerákkal megfigyelt állatok egyedileg is azonosíthatók, viszont erre a legtöbb esetben nincs lehetöség. Ilyenkor a jelenlét/hiány alapú területi felmérések kivitelezhetőbbek. Jelen vizsgálatban a relatív abundanciát a fogási rátával indexeltük (fotók száma / mintavételi egység / nap), amellyel időbeli trendeket hasonlíthatunk össze, figyelembe véve a módszer korlátait (CARBONE et al. 2001). A módszer további hiányosságai között meg kell említeni, hogy nem térképezhető fel teljeskörüen az állatok aktivitása; például a kamerák elsősorban akkor detektálják az állatokat, amikor azok elhagyják földalatti lakhelyüket, vagy a kotorék köz- 
vetlen környezetében tevékenyek. Földalatti aktivitásukat sem tudjuk mérni, mint ahogyan nem tudjuk követni sem a megfigyelt egyedet, miután az elhagyta a kamera látóterét. Mindezen korlátokat az eredmények értelmezésénél figyelembe kell venni.

A vizsgálatban nem csak a megjelenés tényét detektáltuk, hanem a kotoréklakó görény viselkedését is megfigyeltük és kategorizáltuk: 1) érkezik/távozik, 2) tisztálkodik, 3) táplálkozik, 4) figyel, 5) pihen, pl. napozik.

A 6 darab vadkamera molnárgörény és/vagy hörcsög által lakott kotorékok közvetlen közelében lett kihelyezve 2019. március 22. és szeptember 30. között, többféle tesztbeállításban a földfelszínhez közel. A legkisebb távolság kamera és kotorék között $70 \mathrm{~cm}$, a legnagyobb $200 \mathrm{~cm}$ volt. A közeli pozícióval a görény által a kotorékhoz behozott zsákmányokat kívántuk azonosítani. A távolabbi beállítással lehetőség nyílt a kotorékok tágabb környezetének megfigyelésére, illetve a kotorékhoz spontán közelítő egyéb állatok jelenlétének rögzítésére is. A kamera és a kotorék között megritkítottuk az aljnövényzetet, hogy szeles időben a növények elmozdulása ne aktiválja a kamerákat, vagy ne takarják ki a fotózott állatokat. Csalianyagot nem alkalmaztunk. A megfigyelt kotorékok átlagosan 400 méter távolságra helyezkedtek el egymástól.

A megfigyelt molnárgörények a vizsgálat elején befogásra kerültek és a szövetmintáikból kivont DNS alapján molekuláris genetikai módszerekkel (RADseq, újgenerációs szekvenálás és mikroszatellitek elemzése) azonosítottuk őket (al)faji szinten. Minden vizsgálat igazolta, hogy molnárgörény, és nem közönséges görény, vagy a két faj hibridje lakja a kotorékokat. A dél-békési térségböl további 22 görényminta lett feldolgozva és genetikai módszerekkel azonosítva; mind molnárgörénynek bizonyultak (a szerzők és DR. SRAMKÓ GÁBOR, valamint SZATMÁRI LAJOS publikálás alatt lévő eredményei).

A felméréshez Ltl Acorn (Lt15310wa és Lt18210-B) Bushnell (Aggressor és Trophy Cam), Minox (DTC390) és Bushwhacker (BigEye D3) kamerákat használtunk, amelyek főbb tulajdonságaikban megegyeztek. Hibás kameramüködést az egyébként full $H D$ minőségü videók készítésére is alkalmas Bushwhacker kamerák esetében tapasztaltunk: fájlhiba fordult elő, illetve egy eszköz beázott. A meghibásodott eszközöket cseréltük.

A használt kamerák gyors reakcióidővel rendelkeztek $(<1 \mathrm{~s})$ és dátummal, sorszámmal és a kamera azonosítójával feliratozott képeket és videókat készítettek. Beállítás szerint a kamerák 10 másodperces videó-felvétel rögzítése után 20 másodpercig inaktívak voltak minden egyes aktivitás után. Sorozatos felvételeknél csak az 5. perctől elkészített újabb felvételt értelmeztük különálló aktivitási eseménynek. Tehát például, ha a görény 25 percen át a kamera előtt napozott, akkor az csak 5 aktivitási eseményt eredményezett.

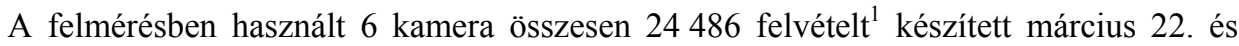
szeptember 30. között.

\section{Statisztikai elemzés}

A vizsgálatokban a két fajra és az egyes évszakokra vonatkoztatva az előfordulások napi adataiból (óra:perc) úgynevezett kernel sürüség becsléssel számítottuk ki az egyes fajok na-

\footnotetext{
${ }^{1}$ A válogatott felvételek megtekinthetők a Bükki Emlőstani Kutatócsoport Egyesület, illetve a szerzők Youtube és Facebook csatornáján.
} 
pi aktivitását adó poligonokat. A kernel sürüség becslés a statisztikában egy nemparaméteres módszer, amelyben egy valószínűségi változó valószínűségi sürüségfüggvényét becsüljük meg (SILVERMAN 1986, SCOTT 2015). Az adataink ábrázolásakor a kernelbecslésnél Gauss-eloszlással simított hisztogramokat alkalmaztunk. Az adatok elemzése és grafikai megjelenítése R statisztikai környezetben (R-TEAM 2015) a „camtrapR” (NIEDBALlA et al. 2016), „circstat” (JAMMALAMADAKA \& SENGUPTA 2001), „circular” (AGOSTINELLI \& LUND 2013), „plotrix” (LEMON 2006) feladatspecifikus csomagjaival történtek.

Az adatainknál becsültük az átfedési együtthatót ( $\Delta 1$, Dhat1), amely kis mintaszám esetén is kiválóan alkalmazható (RIDOUT \& LINKIE 2009; LINKIE \& RIDOUT 2011). Ennek az értéke 1 (teljes átfedés) és 0 (átfedés nélkül) közötti érték lehet. Az adatok elemzésénél MONTERROSO et al. (2014) által is alkalmazott küszöbértékkel dolgoztunk a fajok aktivitási ideje közötti átfedések mértékének minőségi osztályozására (azaz $\Delta 1 \leq 0,66$, alacsony átfedés; $0,66<\Delta 1<0,76$, közepes átfedés; $\Delta 1 \geq 0,76$, nagy átfedés). Az egyes fajok aktivitási mintázatainak napi ciklusai GALBRAITH „radial plot” alkalmazásával is megjelenítésre kerültek (GALBRAITH 1988, GALBRAITH 1990). A kör alakú rácsban a kör szögei a napi időt (óra) mutatják, a diagram pedig az időbeli aktivitási mintázatok sürüségi eloszlását (FISHER 1995). A két faj napi mintázatának megoszlását Watson kétmintás homogenitás teszttel (U2) hasonlítottuk össze (ZAR 1999). A teszt annak a valószínüségét adja meg, hogy a két cirkuláris adatsor származhat-e ugyanabból a populációból.

\section{Eredmények}

A 6 darab kameracsapdával 192 napon át monitoroztuk a kotorékoknál a hörcsög és a molnárgörény aktivitását; a ráfordítás 1152 csapdanap volt. Bár hat kameraállomást üzemeltettünk, ezek közül csak 3-nál volt állandó a molnárgörény jelenléte, tehát az adatok három adult molnárgörény folyamatos megfigyeléséből származnak. A másik 3 kamera lakott hörcsögkotoréknál rögzítette az eseményeket. A kamerákkal megfigyelt búvóhelyeknek nem találtunk több kijáratát egyik faj esetében sem, az állatok a megfigyelt egyetlen nyílást használták. A kotorékok közötti távolságok és átfedő megfigyelési időpontok miatt minimális annak az esélye, hogy ugyanazokat az állatokat figyeltük meg több helyen. A megfigyelések továbbá arra is utalnak, hogy legalább még további kettő molnárgörény példány jelent meg alkalmanként a kameránk elött, köztük egy GPS-es jeladóval nyakörvezett egyed is. Vagyis a $2 \mathrm{~km}$ hosszban vizsgált mezsgyét 4-5 molnárgörény használta, ami kifejezetten magas értéknek tekinthető ahhoz képest, hogy a molnárgörény az ország jelentős részéröl eltünt, vagy egyedsürüsége a kimutathatósági küszöb alatt lehet (CSERKÉSZ et al. unpubl.). Egy kotoréknál figyeltük meg molnárgörény kölykök jelenlétét.

\section{A vadkamerákkal megfigyelt további állatfajok}

A kamerák tesztelését követően a március és november közötti monitoring időszakban 24486 felvétel készült, amelyek közül 17944 felvétel adatait rendeztük adatbázisba. Ezen belül viszonylag magas (7344) azon felvételek száma és aránya (27,6\%), amelyen (1) nem azonosítható a kamera előtt elhaladó állat, (2) a kamera aktivitását nem az állatok mozgása 
váltotta ki, hanem időjárási körülmények, pl. erős szélmozgás, illetve hibás kameramüködésnek köszönhető. A viszonylag rövid vizsgálati időszak alatt azonban ezen tényezők ellenére is fontos és magas információtartalmú felvételek készültek.

Mivel célirányos felvételezést végzetünk, így nem meglepő, hogy - leszámítva az erdeiegereket (Apodemus sp.) - a célfajokról készült a legtöbb felvétel: 6924 hörcsögröl, illetve 1279 molnárgörényről (1. ábra). Színező elemként megjelenik többek között a mogyorós pele (Muscardinus avellanarius), valamint a menyét (Mustela nivalis), és a nyuszt (Martes martes) is. A területről egyébként ismert (helyi vadászok szóbeli közlése) sakálról (Canis aureus) nem készült felvétel és a róka (Vulpes vulpes) aránya is elenyésző (a 0,5\%ot sem éri el) (lásd 1. táblázat).

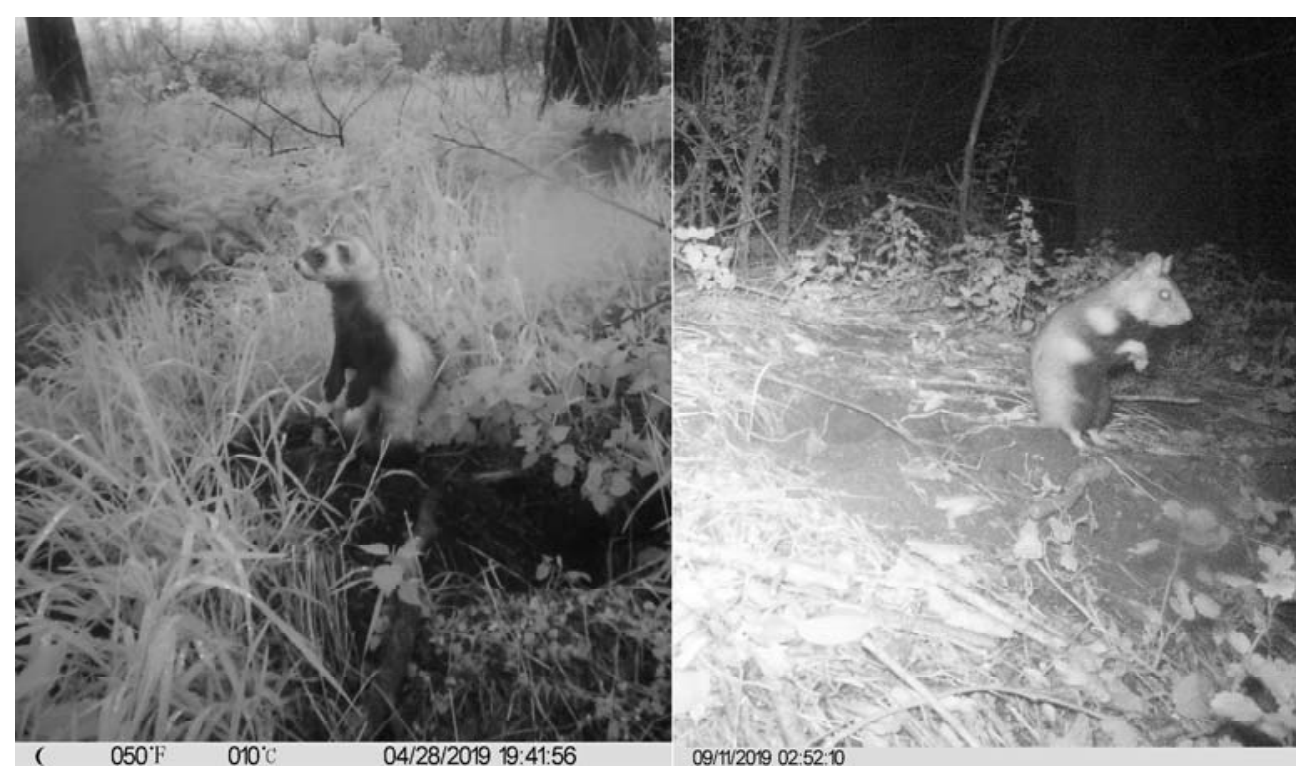

1. ábra. Kameracsapdával készült fényképek molnárgörényröl és mezei hörcsögről.

Figure 1. Images of steppe polecat and common hamster from photographs taken by trail cameras.

\section{Szezonális aktivitás}

Az első molnárgörény március 22-én, már a kamerák kihelyezésének napján, az első hörcsög csak kissé később, április 3-án jelent meg a felvételeken. Március végén és április első felében, tehát a felmérés kezdetén a molnárgörényekről nagy mennyiségben készültek felvételek (673), majd április második felében és májusban a számuk mérséklődött (259), illetve a nyár folyamán már csak alkalmi megfigyelések történtek (összesen 70). A hörcsögfelvételek száma áprilisban és májusban tetőzött (2661 és 2578 felvétel), nyárra viszont töredékére esett vissza (összesen 1307), majd a nyár végére újra emelkedett (2. ábra). 
1. táblázat. Mezökovácsházán, görény és hörcsögkotoréknál készült felvételeken megfigyelt házi és vadonélö állatok összesített listája a felvétek száma és a relatív gyakoriság szerint rendezve.

Table 1. Wildlife and domestic species photographed by trail cameras focused at polecat and hamster burrow entrances in Mezőkovácsháza, Hungary. Percent frequency is the number of photographs of a species divided by the total number of photographs with identifiable animals.

\begin{tabular}{lll}
\hline Detektált faj/taxon & $\begin{array}{l}\text { Felvételek száma (db) } \\
\text { Photos taken }\end{array}$ & $\begin{array}{l}\text { Százalékos arány (\%) } \\
\text { Percent frequency (\%) }\end{array}$ \\
\hline mezei hörcsög (C. cricetus) & 6924 & 65,3 \\
erdeiegér (Apodemus sp.) & 1594 & 15,0 \\
molnárgörény (M. eversmanii) & 1279 & 12,1 \\
európai öz (C. capreolus) & 392 & 3,7 \\
mezei nyúl (L. europaeus) & 151 & 1,4 \\
madár (Aves) & 131 & 1,3 \\
borz (M. meles) & 44 & 0,4 \\
házi macska (F. catus) & 29 & 0,3 \\
vörös róka ( . vulpes) & 27 & 0,3 \\
nyuszt (M. martes) & 9 & 0,1 \\
menyét (M. nivalis) & 6 & 0,1 \\
cickány (Soricidae) & 6 & 0,1 \\
pocok (Microtus sp.) & 3 & 0,0 \\
patkány (Rattus sp.) & 2 & 0,0 \\
mogyorós pele (M. avellanarius) & 2 & 0,0 \\
kutya (C. lupus familiaris) & 1 & 0,0 \\
\hline$\Sigma$ & 10600 & \\
\hline
\end{tabular}

A 7-es számon nyilvántartott, folyamosan lakott görénykotoréknak nőstény lakója volt, ami 4 kölyköt nevelt: július 8-án jelentek meg elöször a kölykök a kotoréknál, de ezután már csak 7 alkalommal figyeltük meg a fiatal egyedeket és anyjukat, ezután feltehetően elköltöztek.

A 8-as számon nyilvántartott, folyamosan lakott görénykotoréknál június 6-án készült az utolsó felvétel a nőstény görényről, ezután nem jelent meg többet a kamera előtt.

A 99-es ideiglenes görénykotorékot a vizsgálat során egyre kevesebbet használta a hím molnárgörény, majd egyre többet a hörcsögök.

\section{Napi aktivitás}

Külön vizsgáltuk a molnárgörény és a hörcsög tavaszi és nyári napi aktivitási mintázatát, majd a két faj adatait együtt elemeztük kernel sürüség becsléssel. Tavasszal a hörcsög és a molnárgörény is tipikus bimodális aktivitást mutat: napnyugta idején és az éjszaka má- 
sodik felében magas aktivitást, míg visszaesését a két csúcs között, éjfél körül regisztráltuk. A két faj tavaszi aktivitás mintázata a Watson-teszt szerint eltérő (U2=6,67; p<0,001), az átfedés közepes mértékü $(\Delta 1=0,66)(3$. ábra). Ez annak köszönhető, hogy este a hörcsög aktivitása később, a görény aktivitás csúcsa után kezdődik, majd hajnalban, a görény második aktivitási csúcsa előtt, korábban fejeződik be.

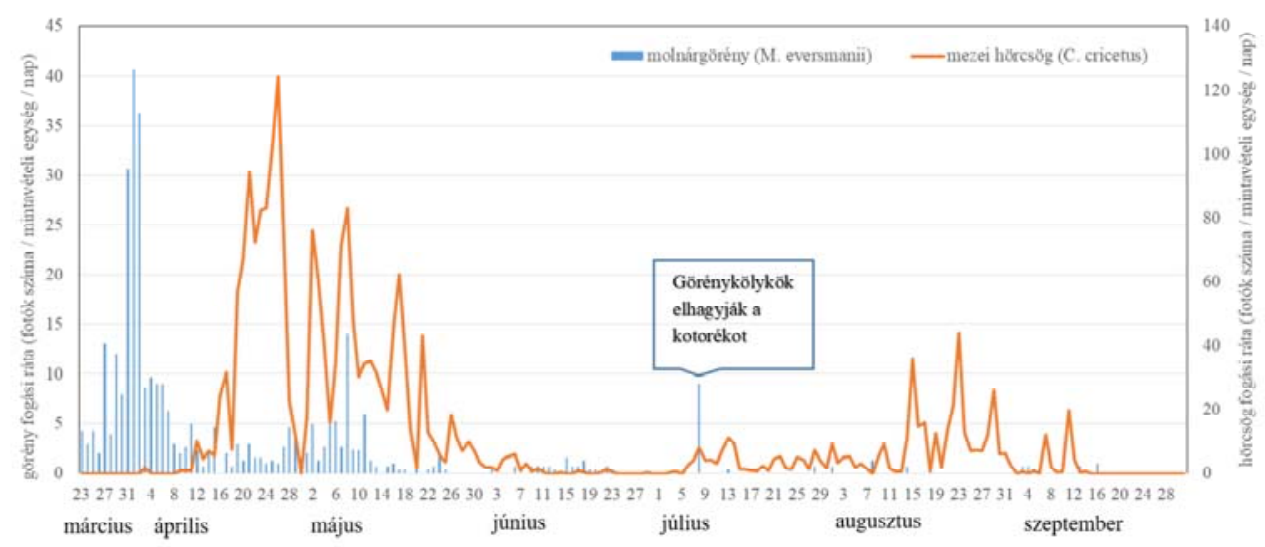

2. ábra. A molnárgörényröl (baloldali y-tengely) és a mezei hörcsögről (jobboldali y-tengely) kameracsapdával rögzített felvételek száma napi felbontásban március és szeptember között.

Figure 2. The number of photographs acquired per day on hamster (right y-axis) and polecat (left y-axis) between March and September.

Nyáron a molnárgörény a tavaszihoz hasonló aktivitási mintázatot mutat, de a hörcsögnél - a tavaszitól eltérően - folyamatos emelkedés figyelhető meg hajnali 4-ig, majd egy hirtelen visszaesés látható. A két faj aktivitási mintázata ebben az időszakban is eltérő $(\mathrm{U} 2=3,12 ; \mathrm{p}<0,001)$, az átfedés alacsonyabb $(\Delta 1=0,3)(4$. ábra). Valószínúleg az alacsony mintanagyság miatt is markánsabb a különbség.

\section{Zsákmány és ragadozó együttélése}

A felvételek kiértékelése lehetővé tette annak meghatározását, hogy a molnárgörény milyen gyakran veszélyezteti a hörcsögöt, azaz mennyi alkalommal hatolt be a hörcsög kotorékába.

A 6-os hörcsögkotorékba 12 alkalommal látogatott el molnárgörény, azonban egyszer sem rögzítették a kamerák, hogy hörcsögöt zsákmányolt volna. Hörcsögkotorékot látogató molnárgörény nem hozott fel zsákmányt a kotorékból, de több esetben is eltünt a kotoréknál egy korábban rendszeresen megfigyelt fiatal hörcsög a görény látogatását követően. A 6-os kotoréknál a molnárgörény távozása után az adult hörcsög egyik esetben 2 perc múlva, míg két másik alkalommal kb. 30 perc elteltével megjelent, így láthatóan egyik alkalommal sem esett áldozatul. Egy esetben a molnárgörény hajnalban jelent meg a hörcsögkotoréknál, és a hörcsög csak aznap este tért vissza az otthonához. A 12-es kotorékot kora tavasszal görény 
használta, de április 10-én eltünt. Ezután hörcsög lakott az üregben. Ekkor egy alkalommal látogatta meg molnárgörény a kotorékot, de nem ejtette el a kotorék lakóját.
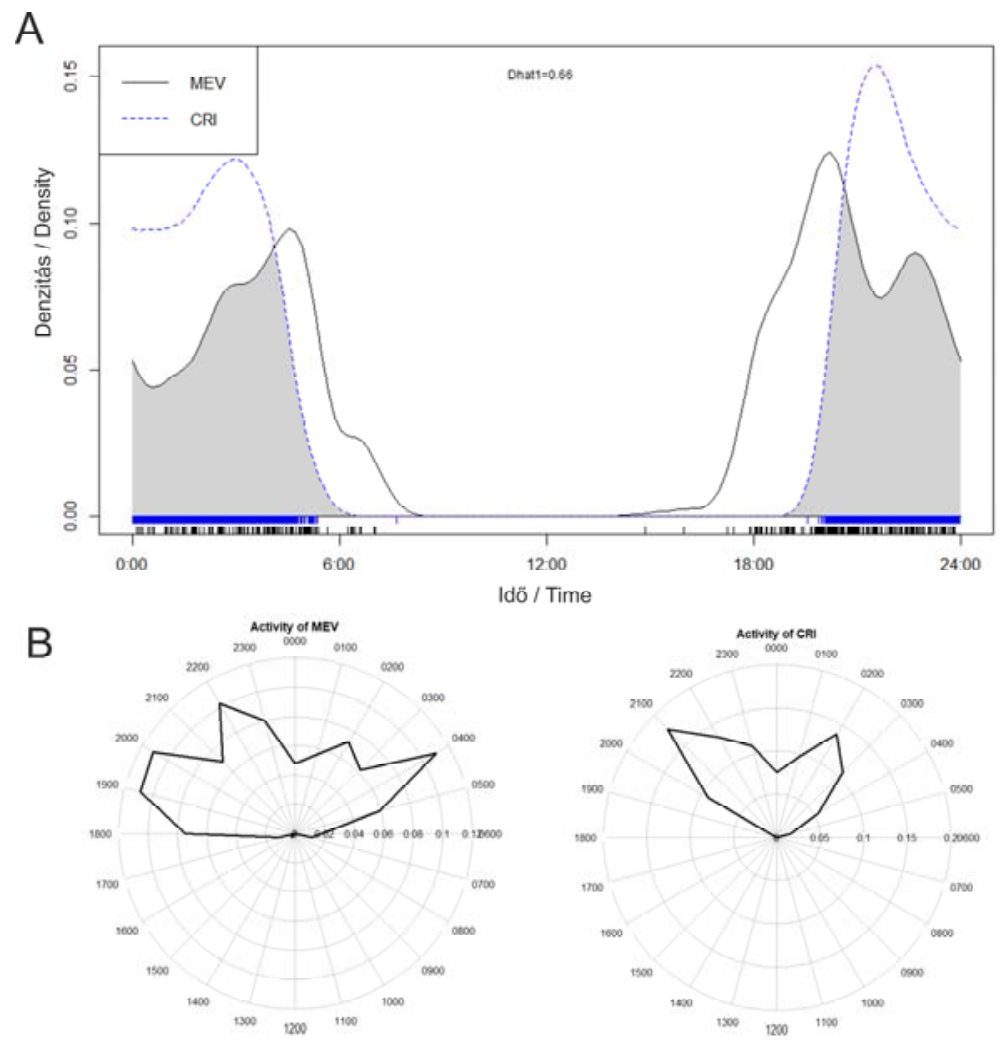

3. ábra. A molnárgörény (MEV) és a hörcsög (CRI) tavaszi, napi aktivitásmintázatának megjelenítése kernel sủrüség becsléssel (A) és kördiagramon (B) kameracsapdákkal gyüjtött adatok alapján. Az átfedési együttható (Dhat1) a két denzitási görbe alatti legkisebb terület (szürkével jelölve az ábrán).

Figure 3. Characterization of diel activity patterns from camera-trap data. Kernel density functions (A) and radial plots (B) were used to depict common hamster (CRI) and steppe polecat (MEV) activity sampled via camera trapping during March-May 2019, in Mezőkovácsháza, Hungary. The overlap coefficient (Dhat1) is the area under the minimum of the two density estimates (denoted in grey).

Szintén vizsgáltuk, hogy milyen gyakran jelenik meg a hörcsög a görény állandó kotorékánál, ahol például az ürülékkupacok miatt erős a szaghatás, és milyen gyakran megy le a görény kotorékába. A 99-es kotorékot 2019. májusában folyamatosan molnárgörény használta, ami 83 felvételen került megörökítésre. Ugyanitt, azonos időben 315 felvétel készült hörcsögről, köztük 43 felvétel arról tanúskodik, hogy a hörcsög lemegy a görény kotorékába. A 7-es és 8-as görénykotorékoknál a teljes vizsgálati periódusban 87 alkalommal jelent meg a hörcsög, de csupán 3 alkalommal ment le a kotorékba. 
Görénykotoréknál csupán 2 alkalommal figyeltük meg, hogy a görény zsákmánnyal érkezett a kotorékához, mindkét alkalommal hörcsögöt hozott.
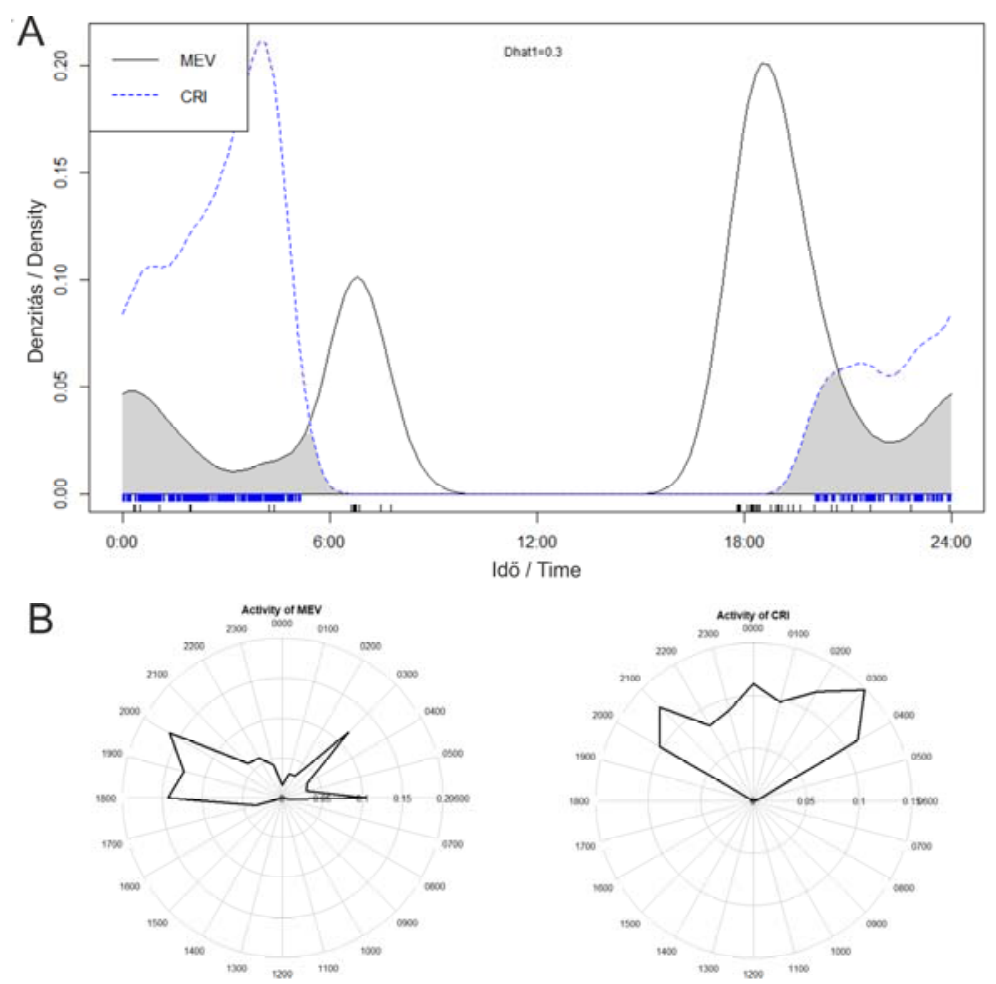

4. ábra. A molnárgörény (MEV) és a hörcsög (CRI) nyári, napi aktivitásmintázatának megjelenítése kernel sủrüség becsléssel (A) és kördiagramon (B) kameracsapdákkal gyüjtött adatok alapján. Az átfedési együttható (Dhat1) a két denzitási görbe alatti legkisebb terület (szürkével jelölve az ábrán).

Figure 4. Characterization of diel activity patterns from camera-trap data. Kernel density functions (A) and radial plots (B) were used to depict common hamster (CRI) and steppe polecat (MEV) activity sampled via camera trapping during June-August 2019, in Mezőkovácsháza, Hungary. The overlap coefficient (Dhat1) is the area under the minimum of the two density estimates (denoted in grey).

\section{Megfigyelések a molnárgörény viselkedéséröl}

A felvételek alapján elmondható, hogy a molnárgörény alapvetően nem tölt sok időt a kotorék előtt. A viselkedésbiológiai szempontból vizsgálható 209 videó-felvétel közül a legtöbb érkezést és távozást örökített meg (65\%). Ritkán látni őket a felvételeken táplálkozás $(1 \%)$, illetve ásás, vagy kaparás közben $(2,5 \%)$. Utóbbi annak köszönhető, hogy már elkészült kotorékokhoz helyeztük ki a kamerát. A kotorék kiásása, méretre igazítása, illetve karbantartása során az állat rendszeresen feljön a kotorékból és akár két lábra állva is szem- 
lét tart környezetében, majd gyorsan folytatja az ásást. Csak ritkán hord táplálékot az állandó lakókotorékához. A felvételek 20\%-án pihenés, illetve a felvételek 11,5\%-án tisztálkodás közben figyeltük meg a görényeket.

\section{Értékelés}

A cikkben bemutatott technikai megoldással most elöször nyílt lehetőség nem-invazív módon betekintést nyerni a molnárgörény életmódjába, amivel megalapozzuk egy ilyen felmérés módszerét. A módszer továbbfejlesztésével és nagyobb térbeli skálán történő felhasználásával jelenlét/hiány, illetve mennyiségi felméréseket is el lehet majd végezni. A mostani kutatásban magas számban és arányban készültek felvételek molnárgörényröl, azonban hiba lenne arra következtetni, hogy az országban, vagy akár csak Békés megye területén véletlenszerüen kihelyezett vadkamerák ilyen mennyiségben készíthetnek felvételt a fajról. A magas esetszám itt a célirányos területválasztás és beállítás eredménye volt, de jelzés értékü, hogy a módszer alkalmas a molnárgörény többcélú kutatására. Más területeken a molnárgörény kimutatása kameracsapdákkal jelentősen hosszabb időt vehet igénybe. Szakirodalmak szerint 1000 csapdaéjszaka szükséges ahhoz, hogy egy ritka ragadozóról nagy biztonsággal kijelenthető legyen, hogy nem fordul elö a vizsgált területen (CARBONE et al. 2001, Kelly \& HoluB 2008).

\section{Szezonális aktivitás mintázat}

Vizsgáltuk az egymás közvetlen közelében élő hörcsög és a molnárgörény aktivitási szintjét. Az aktivitási szint (az idö, amit az állat aktívan tölt) egy viselkedésbiológiai és ökológiai mérőszám, a táplálékszerzési, a szaporodás ráfordítás, de egyúttal a predációs veszély indikátora is (RowCLIFFE et al. 2014). Szabadon élő állatokról általában nehéz erre vonatkozó adatot gyüjteni költséghatékony és nem-invazív módszerrel, ezért a legtöbb fajról hiányosak az ismereteink. Erre a problémára jelent egy viszonylag újfajta megoldást a vadkamerák használata, amellyel költséghatékonyan, az állatok zavarása nélkül lehetséges aktivitási és egyéb adatokat gyüjteni.

Vizsgálatunkban kamerákkal végzett folyamatos megfigyeléssel március és október között gyüjtöttünk aktivitásra vonatkozó adatokat. A vizsgálat októberben zárult, mivel ekkorra az összes megfigyelt görénykotorék lakatlanná vált, illetve a hörcsögök nagy része téli álomra vonult.

A legtöbb európai menyétféle olyan aktivitási ritmust mutat, amely szorosan kapcsolódik a fotóperiódus hosszához, ugyanakkor a meteorológiai vagy élettani tényezők jelentősen befolyásolják ezt a ritmust (SKIRNISSON 1986, RICHARDSON et al. 1987). Ismert például, hogy a menyétfélék csökkentik aktivitásukat hideg időben, vemhesség idején, és fokozzák párzási időszakban, illetve előfordulhat, hogy az adott mintázat a domináns ragadozók elkerülésére irányul (GERELL 1969, ZIELINSKI et al. 1983). A molnárgörénynél a párzási időszak döntően márciusra esik (OTTLECZ 2010), ami fokozott aktivitással jár, így nem meglepő, hogy ebben a hónapban mértük a legmagasabb aktivitási szintet. Hörcsög esetében szintén hasonló okokra vezethető vissza a fokozott májusi aktivitás. A hörcsög és a molnárgörény megfigyelések száma júniusban drasztikusan visszaesett. Ennek legvaló- 
színűbb oka, hogy ekkor a molnárgörények másik kotorékot, vagy búvóhelyet használtak és nem a megfigyeltet. Nyáron már a görény és a hörcsög is többet tartózkodhat a szántóföldek időközben magasra nőtt vetéseiben, itt alakítanak ki új kotorékokat, és nem szorulnak rá a mezsgye nyújtotta fedezékre, de a magas növényzetben az újabb búvóhelyek felkutatására tett kísérleteink eredménytelenül záródtak. A térségben klórfacinon tartalmú rágcsálóirtó szerrel védekeztek a hörcsög és a mezei pocok ellen, így nem zárható ki, hogy akár ennek is köszönhető a megfigyelések számának jelentős nyári visszaesése. A hörcsögök aktivitása ősz felé haladva újra növekedett, majd az utolsó megfigyelés november 6-ra esett.

\section{Napi aktivitás mintázat}

A molnárgörény életmódja kevéssé ismert. A rendelkezésre álló információk (VÁSÁRHELYi 1941, HEPTNER et al. 1967, SZÉKY 1974, WOLSAN 1993, LANSZKI et al. 2007, OTTLECZ 2010, OTTLECZ 2014) egy meglehetősen rejtőzködő, éjszakai ragadozót ábrázolnak. Legközelebbi rokonának, a feketelábú görénynek (Mustela nigripes) az életmódja jobban ismert. Megfigyelték például, hogy több napot is képes inaktívan eltölteni, minden bizonnyal az időjárás és a táplálékkészlet változásának függvényében (RICHARDSON et al. 1987). A molnárgörény és a feketelábú görény rádió-telemetriai vizsgálatai arra utalnak, hogy a görények aktívabbak fényes éjszaka (telihold alkalmával), mint sötét éjszaka, újhold idején, illetve aktívabbak voltak az éjszaka azon részében, amikor holdfény világított (BigGins 2000).

A ragadozók aktivitási mintázata a hatékony zsákmányszerzéshez adaptálódott, míg a zsákmány szerepét betöltő állatok éppen ennek elkerülésére. BAKKER et al. (2005) nyulaknál megfigyelte, hogy aktivitásukat erősen befolyásolja a ragadozó jelenléte; a predációs veszély erősen csökkenti a zsákmány aktivitását és annak mintázata a ragadozó elkerülésére irányul. A zsákmányszerzés is kevesebb ráfordítást igényel, ha a zsákmány aktív, tehát feltételezhetünk egy szinkronizációt a ragadozó és legfontosabb zsákmányának az aktivitása között is. Egyes vizsgálatok szerint a közönséges görény aktivitása például erősen korrelál legfontosabb prédájának aktivitási ritmusával (HERRENSCHMIDT 1982, BLANDFORD 1987, WEBER 1989, LODE 1995). Azonban a molnárgörény és a hörcsög aktivitási szintéjében szezonálisan és napi szinten is találtunk eltérést. Az itt bemutatott eredmények szerint a molnárgörény napi aktivitása átfogja a hörcsögét: minden vizsgált szezonban elöbb kezdödik a hörcsög aktivitásánál és annál később is ér véget és aktivitási csúcsaik sem estek egybe. Ez egyrészt annak lehet köszönhető, hogy a hörcsög csökkentheti aktivitását a görény fö vadászati ideje alatt, azaz próbál kitérni a ragadozó elől, de a sötét periódusra korlátozódó aktivitással valószínűbb, hogy inkább a nappali ragadozó madarak predációs nyomása elől tud kitérni. Módszertani korlát is vezethetett az aktivitási mintázatok különbségéhez: a kotorékokhoz kihelyezett kamerák csak a kotoréknál látják a görényeket, vadászat közben nem. Valójában sokkal nagyobb mértékben átfedhet a két faj aktivitása, mert a kotoréknál csak akkor látjuk a görényt, amikor nem a hörcsögökre vadászik. Az eredmények pontosításhoz növelni kell a nem görénykotorékhoz kihelyezett kamerák számát. Saját GPS-alapú telemetriás vizsgálataink (CSERKÉSZ et al. 2019) szerint a molnárgörény a mezsgyék helyett legtöbbször a nyílt szántóföldeken vadászik, ahol kameracsapdás megfigyelése jelenleg nem megoldható. A hörcsög és a molnárgörény kapcsolatában az időbeli asszociáció azonban valószínűleg kisebb jelentőségü, hiszen a kis és közepes menyétfélék, tehát a molnár- 
görény is, képesek föld alatti kotorékában is követni zsákmányukat (BISCHOF et al. 2014), illetve akkor is kiássák a rágcsálókat, amikor azok inaktívak, például télen (ÉHIK 1928, VÁSÁRHELYI 1941).

\section{Természetvédelmi vonatkozások}

A napi és szezonális aktivitási mintázatok ismerete elengedhetetlen a molnárgörény és a mezei hörcsög viselkedésökológiájának megértéséhez. Viselkedésük és életmódjuk ismerete pedig kritikus jelentőségű e fajok megóvása szempontjából, mivel olyan tényezőket érint, mint a zsákmányszerzés, az élőhelyek használata, az otthon-körzet mérete, az aktivitási mintázatok, illetve nem utolsó sorban a populációk interakciói. Kutatásunk tehát fontos új eredményeket hozott, amelyek felhasználhatók a molnárgörény és a mezei hörcsög megörzését célzó további projektekben is.

Sikeresen demonstráltuk továbbá, hogy csali anyag nélkül beállított rendszerben vadkamerákkal hatékonyan monitorozható szimultán a két faj helyi állománya. A kameracsapdázással kombinált kotorék-térképezéssel sikerült megállapítani, hogy a $2 \mathrm{~km}$ hosszban vizsgált mezsgyét 4-5 molnárgörény használja rendszeresen, ami kifejezetten magas értéknek tekinthető. A molnárgörény az agrárterületek élőhely-generalista ragadozója. Elterjedése és populációmérete azonban erősen függ legfontosabb táplálékállatainak elterjedésétől és mennyiségétől. A vizsgált Békés megyei területen több éve tartósan magas egyedszámot ér el a mezei hörcsög populációja, ami a vadászatára specializált ragadozó, a molnárgörény populációméretének a megerősödését eredményezte (CSERKÉSZ et al. unpubl.).

A molnárgörény-populáció szisztematikus mintavételezése vadkamerákkal és a jelölésvisszafogás módszer alkalmazásával általában pontosabb becslést adna a molnárgörénypopuláció egyedszámáról. Ez a módszer lehetővé tenné a mérési hiba becslését is egy adott helyszínen, és alkalmazható lenne alacsony és magas denzitású populációk esetében is. Ehhez viszont a molnárgörények egyedi azonosítására lenne szükség a felvételeken. A kamerák detektálási rátája összefüggésbe hozható a célfaj helyi abundanciájával, de az így létrehozott indexek vitatottak (ANDERSON 2001, 2003, ENGEMAN 2003), mert kevés tanulmány foglalkozott a kamera detektálási ráta független egyedsürüség becslésekhez történő kalibrációjával. Tigris esetében próbálkoztak ezzel (KARANTH 1995), de az eredményeket többen vitatták (CARBONE et al. 2001, JENNELLE et al. 2002), viszont a szumátrai tigris detektálási rátája korrelált az abundanciával (O'BRIEN et al. 2003).

Természetvédelmi szempontból fontos megfigyelés a rókák alacsony száma a molnárgörény élőhelyén, illetve a sakál hiánya a felvételeken (annak ellenére, hogy a helyi vadászok megfigyelései szerint a sakál kis számban jelen van a vizsgált területen). A róka a molnárgörény és más kis, vagy közepes menyétfélék egyik jelentős ragadozója (HEPTNER et al. 1967, BRIGHT 2000 és saját adatok), így a veszettség elleni immunizálásnak köszönhető állományerősödése feltehetően fontos veszélyeztető tényező a molnárgörény populáció számára. Kutyát csak egy alkalommal figyeltek meg a kamerák, annak ellenére, hogy viszonylag közel található lakott település. Mindebből arra következtethetünk, hogy a térségben a molnárgörénynek kevés a versenytársa és természetes ellensége, legalábbis a szőrmés ragadozók között. A rókapopuláció alacsony szinten tartása, folyamatos gyérítése hosszúés rövidtávon is segíti a molnárgörény fennmaradását. A molnárgörény a hörcsög és a me- 
zei pocok igen hatékony ragadozója, ezért kímélete mezőgazdasági szempontból is hasznos és kívánatos.

A célfajokról történő adatgyüjtésen túl az állandó ráfordítással üzemeltetett vadkamera hálózat az agrár-ökoszisztéma fajgazdagságának monitorozására is alkalmas. A mostani vizsgálat is olyan, a természetvédelem számára fontos fajokról gyüjtött adatokat, mint a molnárgörény, a hörcsög, vagy a mezei nyúl. A mezőgazdaság intenzifikációjának következtében Európában az elmúlt négy évtized során az agrárterületekhez kötődő számos fajnak drámaian csökkent a tömegessége és elterjedtsége, illetve a táplálékhálózatok komplexitása is csökkent (GREGORY et al. 2005, STORKEY et al. 2012, TSIAFOULI et al. 2015). A nyolcvanas évek eleje óta az Európai Unió közös agrárpolitikájának (CAP) beindításával a korábbi tagállamokban az agrárterületeken megdöbbentő mértékủ természeti állapotromlás következett be (THOMAS et al. 2004). Békés megye déli része az utolsó fajgazdag európai agrártájak egyike lehet, ezért természeti értékeinek megőrzésére kiemelt figyelmet szükséges fordítani.

Köszönetnyilvánítás. A felmérés elkészítését a LIFE IP GRASSLAND-HU (LIFE17 IPE/HU/000018) projekt támogatta. Hálás köszönettel tartozunk a Békési tájegység vadászközösségének, elsősorban BOROS FERENC ZsOLT tájegységi fövadásznak, illetve a Körös-Maros Nemzeti Park Igazgatóság munkatársainak, BALOGH-ROTH MELINDÁnak, BÁNFI PÉTERnek és CsATHÓ ANDRÁSnak, amiért hozzájárultak a kutatás gördülékeny kivitelezéséhez. Köszönjük továbbá a kézirat két bírálójának, Dr. HelTAi MikLósnak és Dr. HoRvÁTH GYÖZÖnek a hasznos tanácsait.

\section{Irodalomjegyzék}

Agostinelli, C. \& Lund, U. (2013): R package "circular": circular statistics. $R$ package version 0.47. URL https://r-forge. r-project. org/projects/circular.

Albert, M., Kourkgy, C., Reiners, T. \& Eidenschenck, J. (2014): We Are Watching You! Detection of Common hamsters (Cricetus cricetus) surface activity using wildlife camera traps. In: Reiners, T. \& MACleAN, R. (eds): 21st Annual Meeting of the International Hamster Workgroup. Senckenberg Research Institute, Frankfurt (a.M.) \& Gelnhausen, Germany, pp. 37 38.

ANDERSON, D. R. (2001): The need to get the basics right in wildlife field studies. Wildlife Society Bulletin (1973-2006) 29: 1294-1297.

ANDERSON, D. R. (2003): Response to Engeman: index values rarely constitute reliable information. Wildlife Society Bulletin (1973-2006) 31: 288-291.

BAKKer, E., Reiffers, R., OlfF, H. \& Gleichman, J. (2005): Experimental manipulation of predation risk and food quality: effect on grazing behaviour in a central-place foraging herbivore. Oecologia 146: 157-167. https://doi.org/10.1007/s00442-005-0180-7

BIGGINS, D. (2000): Predation on black-footed ferrets (Mustela nigripes) and Siberian polecats (M. eversmannii): conservation and evolutionary implications. Ph.D. dissertation, Colorado State Univ., Biology Department, 185 pp. 
Bischof, R., Ali, H., Kabir, M., Hameed, S. \& NawaZ, M. A. (2014): Being the underdog: an elusive small carnivore uses space with prey and time without enemies. Journal of Zoology 293: 40-48. https://doi.org/10.1111/jzo.12100

BLANDFORD, P. (1987): Biology of the polecat Mustela putorius: a literature review. Mammal Review 17: 155-198. https://doi.org/10.1111/j.1365-2907.1987.tb00282.x

Bridges, A. S. \& Noss, A. J. (2011): Behavior and activity patterns. In: O'ConNell, A. F., Nichols, J. D. \& KarAnth, K. U. (eds): Camera traps in animal ecology. Springer, pp. 57-69. https://doi.org/10.1007/978-4-431-99495-4_5

BRight, P. W. (2000): Lessons from lean beasts: conservation biology of the mustelids. Mammal Review 30: 217-226. https://doi.org/10.1046/j.1365-2907.2000.00068.x

Carbone, C., Christie, S., Conforti, K., Coulson, T., Franklin, N., Ginsberg, J., Griffiths, M., Holden, J., Kawanishi, K., Kinnaird, M., Laidlaw, R., Lynam, A., Martyr, D., O'Brien, T., Seidensticker, J., Sunquist, M., Tilson, R. \& Shahruddin, W. (2001): The use of photographic rates to estimate densities of tigers and other cryptic mammals. Animal Conservation 4: 75-79. https://doi.org/10.1017/S1367943001001081

Chetri, M., Odden, M., McCarthy, T. \& Wegge, P. (2014): First record of Steppe Polecat Mustela eversmanii in Nepal. Small Carnivore Conservation 51: 79-81.

Csathó, A. I., Csathó, A. J., Sztankó, M. \& VégváRi, Z. (2016): A mezei hörcsög (Cricetus cricetus) populációdinamikájának hosszú távú vizsgálata gépjármüvek által elütött példányok felmérésével (1995-2015). In: Csorba, G., KovÁCs-HostyánSZKi, A., NÉMETH, A., SzEPESVÁry, C., Vili, N. (eds): X. Magyar Természetvédelmi Biológiai Konferencia: Mühelytalálkozó „Zászlóshajók, karizmák és esernyők: mit tehet az emlőskutatás a természetvédelemért”. Magyar Biológiai Társaság, Mórahalom, p. 55.

CSERKÉSz, T. (2017): A mezei hörcsög aktuális helyzete. In: Holes, A. (ed.): Magyarország környezeti állapota 2016. Herman Ottó Intézet, Budapest, pp. 76-81.

Cserkész, T., Kiss, C. \& OtTLecz, B. (2019): Molnárgörény kutatása Békés megyében GPSnyakörves telemetriai módszerrel. Készült a Körös-Maros Nemzeti Park Igazgatóság megbízásából. Bükki Emlőstani Kutatócsoport Egyesület, Eger, 20 pp.

ÉHIK, G. (1928): A mezei görény (Mustela eversmanni Less.) hazánkban. Annales historico-naturales Musei nationalis hungarici 25: 1-38.

Elmeros, M., Lassen, P., Bossi, R. \& Topping, C. J. (2018): Exposure of stone marten (Martes foina) and polecat (Mustela putorius) to anticoagulant rodenticides: Effects of regulatory restrictions of rodenticide use. Science of The Total Environment 612: 1358-1364. https://doi.org/10.1016/j.scitotenv.2017.09.034

Engeman, R. (2003): More on the Need to Get the Basics Right: Population Indices. Wildlife Society Bulletin 31: 286-287.

FefELov, I. (2004): Observations on the nesting of Imperial Eagle Aquila heliaca in the Kuitun-Zima steppe area, Baikal region, Russia. Forktail 20: 145-146.

FISHER, N. I. (1995): Statistical analysis of circular data. Cambridge University Press, 277 pp.

Galbraith, R. F. (1988): Graphical display of estimates having differing standard errors. Technometrics 30: 271-281. https://doi.org/10.1080/00401706.1988.10488400

GALBRAith, R. F. (1990): The radial plot: graphical assessment of spread in ages. International Journal of Radiation Applications and Instrumentation. Part D. Nuclear Tracks and Radiation Measurements 17: 207-214. https://doi.org/10.1016/1359-0189(90)90036-W

Gerell, R. (1969): Activity Patterns of the Mink Mustela vison Schreber in Southern Sweden. Oikos 20: 451-460. https://doi.org/10.2307/3543208 
Gregory, R. D., van Strien, A., Vorisek, P., Gmelig Meyling, A. W., Noble, D. G., Foppen, R. P. B. \& GibBons, D. W. (2005): Developing indicators for European birds. Philosophical Transactions of the Royal Society B: Biological Sciences 360: 269-288. https://doi.org/10.1098/rstb.2004.1602

Heptner, V., Naumov, N., Yurgenson, P., Sludsky, A., Chirkova, A. \& Bannikov, A. (1967): Mammals of the USSR. Sirenia and Carnivora 2. Vysshaya Shkola, Moscow, 1004 pp.

HerRenschmidt, V. (1982): Note sur les déplacements et le rythme d'activité d'un putois, Mustela putorius L., suivi par radiotracking. Mammalia 46: 554-556.

Horváth, M., Solti, B., FAtér, I., Juhász, T., Haraszthy, L., SzitTa, T., Ballók, Z. \& PÁsztoryKovÁCS, S. (2018): Temporal changes in the diet composition of the Eastern Imperial Eagle (Aquila heliaca) in Hungary. Ornis Hungarica 26: 1-26. https://doi.org/10.1515/orhu-2018-0001

Jammalamadaka, S. R. \& Sengupta, A. (2001): Topics in circular statistics. World Scientific, Singapore, $336 \mathrm{pp}$. https://doi.org/10.1142/4031

Jennelle, C. S., Runge, M. C. \& MacKenzie, D. I. (2002): The use of photographic rates to estimate densities of tigers and other cryptic mammals: a comment on misleading conclusions. Animal Conservation Forum 5: 119-120. https://doi.org/10.1017/S1367943002002160

KARANTH, K. U. (1995): Estimating tiger Panthera tigris populations from camera-trap data using capture-recapture models. Biological Conservation 71: 333-338. https://doi.org/10.1016/00063207(94)00057-W

Kelly, M. J. \& Holub, E. L. (2008): Camera Trapping of Carnivores: Trap Success among Camera Types and across Species, and Habitat Selection by Species, on Salt Pond Mountain, Giles County, Virginia. Northeastern Naturalist 15: 249-262. https://doi.org/10.1656/10926194(2008)15[249:CTOCTS]2.0.CO;2

KirÁly, G., MolnÁr, Z., BÖlÖNI, J., Csiky, J. \& VoJTKó, A. (2008): Magyarország földrajzi kistájainak növényzete. MTA Ökológiai és Botanikai Kutatóintézete, Vácrátót, 248 pp.

KryštufeK, B., Vohralík, V., Meinig, H. \& Zagorodnyuk, I. (2016): Cricetus cricetus (errata version published in 2017). The IUCN Red List of Threatened Species 2016: e.T5529A115073669. https://dx.doi.org/10.2305/IUCN.UK.2016-3.RLTS.T5529A22331184.en.

LANSZKi, J., HeltAi, M. \& LeHOCZKY, R. (2007): Molnárgörény (Mustela eversmanii). In: BiHARI, Z., Csorba, G., Heltai, M. (eds): Magyarország emlőseinek atlasza. Kossuth Kiadó, Budapest, Hungary, pp. 230-231.

LEMON, J. (2006): Plotrix: a package in the red light district of R. R-news 6: 8-12.

Linkie, M. \& Ridout, M. S. (2011): Assessing tiger-prey interactions in Sumatran rainforests. Journal of Zoology 284: 224-229. https://doi.org/10.1111/j.1469-7998.2011.00801.x

Lode, T. (1995): Activity Pattern of Polecats Mustela putorius L. in Relation to Food Habits and Prey Activity. Ethology 100: 295-308. https://doi.org/10.1111/j.1439-0310.1995.tb00334.x

Maran, T., Skumatov, D., Abramov, A. \& Kranz, A. (2016): Mustela eversmanii. The IUCN Red List of Threatened Species 2016: e. T29679A45203762.

Meyburg, B. \& Kirwan, G. (2020): Eastern Imperial Eagle (Aquila heliaca). In: Del Hoyo, J., Elliott, A., Sargatal, J., Christie, D.A. \& De Juana, E. (eds): Handbook of the Birds of the World Alive. Lynx Edicions, Barcelona, Spain, pp. 194-195, plate 20.

https://doi.org/10.2173/bow.impeag 1.01

Monterroso, P., Alves, P. C. \& Ferreras, P. (2014): Plasticity in circadian activity patterns of mesocarnivores in Southwestern Europe: implications for species coexistence. Behavioral Ecology and Sociobiology 68: 1403-1417. https://doi.org/10.1007/s00265-014-1748-1 
Niedballa, J., Sollmann, R., Courtiol, A. \& Wilting, A. (2016): camtrapR: an R package for efficient camera trap data management. Methods in Ecology and Evolution 7: 1457-1462. https://doi.org/10.1111/2041-210X.12600

O'Brien, T. G., KinNAIRD, M. F. \& Wibisono, H. T. (2003): Crouching tigers, hidden prey: Sumatran tiger and prey populations in a tropical forest landscape. Animal Conservation 6(2): 131-139. https://doi.org/10.1017/S1367943003003172

O'Connell, A. F., Nichols, J. D. \& Karanth, K. U. (2010): Camera traps in animal ecology: methods and analyses. Springer, Tokyo, 271 pp. https://doi.org/10.1007/978-4-431-99495-4

Ottlecz, B. (2010): Egy ismeretlen menyétféle: a molnárgörény. In: Heltai, M. (ed.): Emlősragadozók Magyarországon. Mezőgazda Kiadó, Budapest, pp. 155-163.

OtTleCZ, B. (2014): Molnárgörény Mustela eversmanii Lesson, 1827. In: HaraszThY, L. (ed.): Natura 2000 fajok és élöhelyek Magyarországon. Pro Vértes Közalapítvány, Csákvár, pp. 709711.

Ottlecz, B., Csathó, A., Sramkó, G. \& Cserkész, T. (2019): Ismerjük meg a titokzatos molnárgörényt. Bükki Emlőstani Kutatócsoport Egyesület, Eger, 8 pp.

R-TeAm (2015): RStudio: integrated development for R. RStudio, Inc., Boston, MA URL http://www.rstudio.com 42: 14.

Richardson, L., Clark, T. W., Forrest, S. C. \& Campbell III, T. M. (1987): Winter ecology of black-footed ferrets (Mustela nigripes) at Meeteetse, Wyoming. American Midland Naturalist 117(2): 225-239. https://doi.org/10.2307/2425964

Ridout, M. S. \& LinKIE, M. (2009): Estimating overlap of daily activity patterns from camera trap data. Journal of Agricultural, Biological, and Environmental Statistics 14: 322-337. https://doi.org/10.1198/jabes.2009.08038

RÓNAI, A. (1983): A Körös-medence földtörténete a negyedkorban. Földtani Közlöny 113: 1-25.

Rovero, F. \& Zimmermann, F. (2016): Camera trapping for wildlife research. Pelagic Publishing Ltd, Exeter, UK, $320 \mathrm{pp}$.

Rowcliffe, J. M., Kays, R., Kranstauber, B., Carbone, C. \& Jansen, P. A. (2014): Quantifying levels of animal activity using camera trap data. Methods in Ecology and Evolution 5: 1170-1179. https://doi.org/10.1111/2041-210X.12278

ScotT, D. W. (2015): Multivariate density estimation: theory, practice, and visualization. John Wiley \& Sons, 336 pp. https://doi.org/10.1002/9781118575574

Silverman, B. W. (1986): Density Estimation for Statistics and Data Analysis. Taylor \& Francis, New York, 176 pp. https://doi.org/10.1007/978-1-4899-3324-9

SKIRNISSON, K. (1986): Untersuchungen zum Raum-Zeit System freilebender Steinmarder (Martes foina Erxleben, 1777). Beitr. Wildbiol. 6: 1-200.

Storkey, J., Meyer, S., Still, K. S. \& Leuschner, C. (2012): The impact of agricultural intensification and land-use change on the European arable flora. Proceedings of the Royal Society B: Biological Sciences 279: 1421-1429. https://doi.org/10.1098/rspb.2011.1686

SÜMeghy, J. (1944): A Tiszántúl. Magyar tájak földtani leírása VI. Földt. Int. Ny.: M. Kir. Honv. Térk. Int., 208 pp.

SzÉKY, P. (1974): Adatok a magyarországi mezei görény (Putorius eversmanni hungarica Éhik) biológiájához. In: Soós, P., Manczel, J. \& Stefanovits, P. (eds): Gödöllői Agrártudományi Egyetem Közleményei. Gödöllői Agrártudományi Egyetem, Gödöllö, pp. 45-61. 
Thomas, J. A., Telfer, M. G., Roy, D. B., Preston, C. D., Greenwood, J., Asher, J., Fox, R., Clarke, R. T. \& Lawton, J. H. (2004): Comparative losses of British butterflies, birds, and plants and the global extinction crisis. Science 303: 1879-1881.

https://doi.org/10.1126/science.1095046

Tikhonov, A., Cavallini, P., Maran, T., Kranz, A., Stubbe, M., KryštufeK, B., Abramov, A. \& WozenCRAFT, W. C. (2007): Mustela eversmanii. Scope of Assessment: Europe. The IUCN Red List of Threatened Species 2007 e.T29679A9525197.

Tsiafouli, M. A., Thébault, E., Sgardelis, S. P., De Ruiter, P. C., Van der Putten, W. H., Birkhofer, K., Hemerik, L., de Vries, F. T., Bardgett, R. D., Brady, M. V., Bjornlund, L., Jørgensen, H. B., Christensen, S., Hertefeldt, T. D., Hotes, S., Gera Hol, W. H., Frouz, J., Liiri, M., Mortimer, S. R., Setälä, H., Tzanopoulos, J., Uteseny, K., Pižl, V., Stary, J., Wolters, V. \& HEDlund, K. (2015): Intensive agriculture reduces soil biodiversity across Europe. Global Change Biology 21: 973-985. https://doi.org/10.1111/gcb.12752

VÁSÁRHELYI, I. (1941): Adatok a mezei görény életmódjához. Vadászújság 1: 41.

Villemey, A., Besnard, A., GrandadAM, J.\& EidensChenCK, J. (2013): Testing restocking methods for an endangered species: Effects of predator exclusion and vegetation cover on common hamster (Cricetus cricetus) survival and reproduction. Biological Conservation 158: 147-154. https://doi.org/10.1016/j.biocon.2012.08.007

WeBer, D. (1989): Beobachtungen zu Aktivität und Raumnutzung beim Iltis (Mustela putorius L.). Rev. suisse zool 96: 841-862. https://doi.org/10.5962/bhl.part.117775

WeinHold, U. (2008): Draft European action plan for the conservation of the common hamster (Cricetus cricetus L., 1758). Convention on the conservation of European wildlife and natural habitats, Standing Commitee. Council of Europe, Strasbourg, France, pp. 1-36.

Wolsan, M. (1993): Mustela eversmanni Lesson, 1827-Steppeniltis In: NeITHAMmer, J., KRAPP, F. (eds): Handbuch der Säugetiere Europas. Aula-Verlag, Wiesbaden, pp. 770-816.

ZAR, J. H. (1999): Biostatistical analysis, 4th ed. Prentice Hall, 929 pp.

Zielinski, W. J., Spencer, W. D. \& Barrett, R. H. (1983): Relationship between Food Habits and Activity Patterns of Pine Martens. Journal of Mammalogy 64: 387-396.

https://doi.org/10.2307/1380351 


\title{
Coexistence of prey and predator in agricultural land: diel and seasonal activity patterns of common hamster (Cricetus cricetus) and steppe polecat (Mustela eversmanii) at burrows
}

\author{
TAMÁS CSERKÉSZ ${ }^{1}$, CSABA KISS ${ }^{2}$ \& BARNABÁS OTTLECZ ${ }^{2}$ \\ ${ }^{1}$ Hungarian Natural History Museum, Department of Zoology, Baross u. 13. H-1088 Budapest, Hungary \\ ${ }^{2}$ Bükk Mammalogical Society, Maklári út 77/A H-3300 Eger, Hungary \\ *E-mail: cserkesz.tamas@nhmus.hu
}

ÁLLATTANI KÖZLEMÉNYEK (2020) 105(1-2): 95-113.

\begin{abstract}
The spring and summer activity patterns of the Common hamster and its specialized predator, the Steppe polecat were investigated using camera traps in a $2 \mathrm{~km}$ long section of baulk surrounded by ploughlands in the southern part of Békés County, Hungary. No similar study on steppe polecats has been conducted yet, so we present several completely novel results. At least 4-5 polecats occupied this section of baulk during the study period, which is considered to be an exceptionally high density. The hamster is also common here, even though it is subjected to eradication campaigns. Seasonal activity peaked in spring for both species, which may be due to the mating season. In spring, the daily activity of hamsters and polecats overlapped more than in summer $(\Delta 1=0.66$ in spring, $\Delta 1=0.3$ in summer). The beginning of the polecats' active period was ahead of the hamster's activity in both seasons and ended later, so it covered the whole active phase of the prey. In summer, fewer observations were recorded, probably due to the fact that arable fields covered by taller vegetation were increasingly used by both species, and they did not rely on the shelter provided by the baulk. In summer, the polecat activity retained its bimodal character, whereas the hamster showed a 'complementary' unimodal pattern, presumably aimed to avoid the predators. The Red fox, a significant predator of both hamsters and polecats, has been registered as a rare visitor in the study area due to active hunting. The low number of red foxes may contribute to the survival of the viable steppe polecat population in Békés County.
\end{abstract}

Keywords: trail camera, kernel density analysis, endangered species.

Accepted: 13.04 .2020

Published online: 08.05 .2020 